\title{
Determinants of individual-level social capital: Culture and personal values
}

\author{
Anneli Kaasa \\ School of Economics and Business Administration, \\ University of Tartu \\ Estonia \\ anneli.kaasa@ut.ee
}

\begin{abstract}
The main aim of this multilevel analysis is to examine both personal values and cultural context as possible determinants of the individual-level social capital. The data pertaining to over 56,000 respondents from 85 regions are analysed with the help of multilevel regression analysis. The novelty of this article lies in incorporating a systematic approach covering many social capital dimensions, a multilevel analysis of the individual-level social capital including cultural context and also involving personal values as possible determinants of the individual-level social capital. The findings show that cultural context is important for individuals' social capital and the results even imply that cultural context is more important in determining the level of individuals' social capital than personal values. Some of the supposed impact of the communist past or the religious context on the level of social capital can be captured and explained by the cultural dimensions as well.
\end{abstract}

Keywords: Social Capital, Cultural Context, Personal Values, Europe.

JEL Classification: A13, A14, R10, Z12, Z13.

\section{INTRODUCTION}

Social capital has been actively discussed and commonly acknowledged in literature as an important factor of economic development. Hence, it is necessary to understand what determines the level of social capital. As social capital consists of and derives from attitudes and actions of people - varying in different countries and regions - it can be supposed that the values forming those attitudes and driving people's actions have an important role here. However, while different individual-level and society-level factors have been widely discussed in various studies (e.g., Fidrmuc \& Gërxhani, 2005; van Oorschot \& Arts, 2005; Halman \& Luijkx, 2006; van Oorschot et al., 2006; Kaasa \& Parts, 2008; Berggren \& Bjørnskov, 
2011; Christoforou, 2011; Mondéjar-Jiménez et al., 2011), values have not received much attention as factors of social capital with only a few studies tackling this relationship. Allik and Realo (2004) analysed the relationship between individualism and social capital at the society level, while Halman and Luijkx (2006) included individualism and moral sense at both the society and individual levels. As a first attempt to provide a more systematic approach, Kaasa (2015) in her society-level study investigated the relationship of Hofstede's cultural dimensions with five different dimensions of social capital. However, social capital can be analysed at the level of society - as an attribute of a country or a region (Portes, 1998; Putnam, 1995) - as well as at the individual level - as an asset of an individual (e.g., Bourdieu, 1986; Coleman, 1988). When looking for the determinants of the individual-level social capital, although the culture surrounding individuals can definitely be expected to have an influence, it is reasonable to assume that personal values of those individuals are relevant as well.

Here, an interesting question can be raised: which is more important in shaping the social capital of an individual - personal values or the cultural context and values dominating in the society? This article intends to shed some light on this question. As a novelty, this article incorporates; (1) a systematic approach covering many social capital dimensions, (2) a multilevel analysis of the individual-level social capital including the cultural context, and (3) personal values as possible determinants of the individuallevel social capital.

The main objective of this multilevel analysis is to examine both personal values and cultural context as possible determinants of social capital. Four different social capital dimensions are included. The individual-level data are taken from the European Social Survey (ESS, 2008) and complemented with the regional-level data from different sources. The regional level was chosen because significant differences within countries with regard to culture have been demonstrated (Beugelsdijk et al., 2006; Kaasa et al., 2013; 2014). In addition, using within-country regions as society-level units increases the number of society-level observations and enables obtaining more reliable results. The data pertaining to over 56,000 respondents from 85 regions are included into the analysis. The cultural context is operationalised using Hofstede's cultural dimensions with the help of data from (Kaasa et al., 2014), offering a point of comparison for the results of (Kaasa, 2015). At the individual level, various indicators of personal values stemming from the ESS are included, based on the theoretical assumptions. Multilevel regression analysis is used as the main method to examine possible individual-level and society-level determinants of different dimensions of the individual-level social capital. The main results show that cultural context is important for the level of individuals' social capital and at that, cultural context is more important in determining the level of individuals' social capital than personal values.

This article is structured as follows. After this introduction, Section 2 presents the theoretical background and Section 3 introduces the data and operationalisation. Section 4 reports and Section 5 discusses the results. Section 6 draws conclusions and points out the limitations.

\section{THEORETICAL BACKGROUND}

This article focuses on the individual-level social capital. There are many definitions of social capital in the literature. For example, Adler and Kwon (2002) and Tamaschke (2003) provide exhaustive overviews of different definitions. In this article, similarly to Kaasa and Parts (2008), the individual-level social capital is viewed as an asset of an individual consisting of various elements related to trust and networks or more precisely: cognitive and structural social capital. While the cognitive aspect is associated with attitudes and norms and encompasses, for example, general and institutional trust, the structural aspect is related rather to actions comprising participation in different networks as well as civic participation (Hjøllund \& Svendsen, 2000; Kaasa \& Parts, 2008). It is important to differentiate between 
the various dimensions of social capital as their sources may differ significantly (van Oorschot et al., 2006; Halman \& Luijkx, 2006; Kaasa \& Parts, 2008; Mondéjar-Jiménez et al., 2011).

The attitudes and actions people's social capital consists of can be assumed to be influenced by values. The dominating values in a society can be captured into a concept of culture. From the many approaches and definitions of culture (see, e.g. Hall, 1980; Chanchani \& Theivanathampillai, 2002; Taras et al., 2009), here the sociological approach is chosen, defining culture as personal values, beliefs and behaviours shared by a group of people, be it a country or a region (Hofstede, 1980; Schwartz, 2011). Cultures can be described with the help of different dimensions that constitute a multidimensional space where every culture can be shown as a point in that space. Various sets of cultural dimensions have been offered in the literature (Parsons \& Shils, 1951; Kluckhohn \& Strodtbeck, 1961; Hofstede, 1980; Schwartz, 1994; Trompenaars \& Hampden-Turner, 1997; Inglehart \& Baker, 2000; House et al., 2002). Following Kaasa (2015), in this article Hofstede's (1980) original approach is chosen that offers four dimensions: power distance, uncertainty avoidance, masculinity (as opposed to femininity) and individualism (as opposed to collectivism). Although this approach has often been criticised (see Chiang, 2005; Oyserman et al., 2002; McSweeney, 2002; Gooderham \& Nordhaug, 2001 for examples), much of the criticism addresses rather the measurement problems and this approach is still the one that is most widely used in both the theoretical and empirical literature.

Concerning the possible impact of cultural dimensions on social capital, the literature is very scarce. There has been some discussion about the individualism-collectivism dimension as a possible factor of social capital (Allik \& Realo, 2004; Halman \& Luijkx, 2006; Mondéjar-Jiménez et al., 2011), but the only study discussing all Hofstede's dimensions so far is the society-level study of Kaasa (2015). There are also some studies comparing different country groups across Europe (van Oorshot \& Arts, 2005; van Oorschot et al., 2006; Christoforou, 2011; Berggren \& Bjørnskov, 2011) that all show differences in the social capital levels between those groups, thus referring that there might be something in the culture that causes these differences. Besides the geographical division often pointing out Northern and/or Mediterranean countries, another division is based on having a communist background which might be seen as an important impact factor for various reasons (see Kaasa, 2015 for an overview). However, while some of the reasoning behind these differences is related to the time factor (for instance, old networks were mostly dropped during transition and it takes time to build new ones), it might be possible to explain many of the differences with the cultural background, for example with high levels of power distance that developed during the communist past. Hence, it is questionable if it is the communist background per se that causes the differences in social capital, or if the reasons could be captured simply with the cultural dimensions - the level of which, however, might naturally be affected by the communist past.

Next, Hofstede's $(1980,2001)$ four cultural dimensions are discussed as important characteristics of the environment where the individuals' social capital is shaped. First, power distance shows the degree to which hierarchic relations and the unequal distribution of power are regarded as acceptable in a society. More centralised decision structures and more formal rules can be found in the case of larger power distance. Hence, as there is less opportunity to be involved in decision-making, people might have adopted a more fatalistic view waiting for authorities to act and not engaging actively in social processes (Kaasa, 2015). This might impact both participation and networks, but also trust and especially trust in institutions. This is also confirmed by the society-level study of 85 European regions performed by Kaasa (2015) where power distance appeared to be negatively related to general and institutional trust as well as formal and informal networks. The impact of the communist past has often been described in a similar vein: during the communist times, there were strict rules, restrictions and sanctions that hindered people's own initiative, but also having a job, accommodation and other services were assured (Fidrmuc \& Gërxhani, 2005; Bjørnskov, 2006; Kaasa, 2015). Hence, it might be possible to capture much of the 
communist background with the power distance dimension. Regarding other possible impact mechanisms, it has been argued that in the case of larger power distance, people might view equality as more important than freedom and emphasise cooperation more, similarly to the argument related to the left-right distinction (Halman \& Luijkx, 2006; van Oorschot et al., 2006; Kaasa, 2015) where left-wing ideology favours equality and cooperation and right-wing ideology puts stress on the free market and the freedom of individuals. However, it is questionable whether the more unequal distribution of power in the case of larger power distance necessarily means a demand for more equal distribution, as the power distance is rather about people accepting the unequal distribution of power in a society.

Second, uncertainty avoidance describes how comfortable people feel with ambiguous situations and uncertainty. While in societies with low uncertainty avoidance ambiguous situations are regarded as natural, in the case of high uncertainty avoidance rules play an important role in offering assurance. It is logical to expect, as also pointed out by Kaasa (2015), that people in societies with high uncertainty avoidance are less trusting and it might hinder cooperation between individuals as well since it is related to the risk of making an effort and not receiving enough back. All this is expected to have consequences when it comes to general and institutional trust as well as participation and networks. Kaasa (2015) found uncertainty avoidance to be negatively related to general trust, formal networks and civic participation. The relationship with informal networks, however, turned out to be positive, the possible explanation being that people who rather avoid new contacts in the form of formal organisations and civic participation still have to find ways to cope with uncertainty and here the informal networks consisting of close friends and relatives (being more familiar) play an important role (Kaasa, 2015). The discussion of the impact of the communist background also addresses uncertainty: the rapid and drastic changes during transition might have contributed to the development of cautious attitudes, but more importantly, the danger of being punished for non-approved behaviour and the possibility that this behaviour could be reported even by close acquaintances supported the development of an untrusting milieu (Sztompka, 2000; Drnakova, 2006; Kaasa et al., 2011, Kaasa, 2015).

Third, masculinity (as opposed to femininity) reflects to what extent masculine values like success and achievement dominate over feminine values such as caring, solidarity and tolerance. As good relationships are valued more highly in more feminine societies, cooperation can be expected to be in favour more and this is expected to encourage people to participate. Also, as the mentality is more tolerant and the belief in group decisions stronger (Kaasa, 2015), it can be expected that people have higher levels of general and institutional trust. This is also confirmed by the analysis of Kaasa (2015) where both general and institutional trust, informal networks and civic participation turned out to be negatively related to masculinity. Formal networks, however, appeared to be positively related to masculinity; possibly because participation in formal networks enables to satisfy the needs for achievement and assertiveness related to masculinity (Kaasa, 2015).

Last, individualism (as opposed to collectivism) reveals whether people prefer to act as individuals rather than as members of a group. While in individualist societies autonomy and individual freedom are regarded as important, in collectivist societies belonging and the support of a group are highly valued. Hence, it seems that cooperation, participation and networks might be encouraged by collectivist views while in individualist societies people are more egoistic and less interested in participation (Halman \& Luijkx, 2006; Kaasa, 2015). At the same time, in more individualist societies, people might feel more free and liberated from social pressure and that might make them more trusting and motivated to show their opinion and engage in social processes (Allik \& Realo, 2004; Kaasa, 2015). In addition, in collectivist societies people can be expected to rely more on the group's support in exchange for loyalty (Kaasa, 2015) and this more passive mentality rather hinders participation. The empirical results here are mixed. Allik and Realo (2004) analysed both cross-country data and data from the US and found individualism to be 
positively related to interpersonal trust and organisational membership. At the same time, Halman and Luijkx (2006) showed less interpersonal trust and importance given to being socially active in the case of higher levels of individualism. However, they had also included personal values into the analysis which might have affected the results. More recently, Kaasa (2015) found individualism to be positively related to only two social capital dimensions: civic participation, for which the reasoning related to having more motivation to engage in social processes and to express opinions is most relevant, and institutional trust which is logically related to the feeling of participating.

Besides the cultural context, the personal values of individuals can undoubtedly be expected to have some influence on their social capital. However, personal values have been included into very few studies of the individual-level social capital so far. Berry and Rickwood (2000) analysed Australian data and found that the security values were related to lower community trust and less community participation while the harmony values were only related to the trust towards friends. Halman and Luijkx (2006) in their multilevel study of European data used two factors created with the help of factor analysis in order to measure individuals' personal values. First, they joined questions about valuing making own decisions, being creative and being successful to a factor they called individualism at the individual level. This factor appeared to be negatively related to interpersonal trust, unrelated to institutional trust and positively related to the importance given to being socially and formally active. Second, they incorporated questions about valuing being modest, behaving properly, helping people and loyalty to friends in a factor called moral sense. This factor turned out to be positively related to all dimensions of social capital analysed, except interpersonal trust. Mondéjar-Jiménez et al. (2011) analysed the individual-level data of five Central European countries and included a factor they named collectiveness that was made up of various questions describing attitudes towards income equality, the government's responsibility, private ownership, competition, wealth accumulation, etc. This factor was reported to be positively related to institutional trust, social and political participation.

It has been argued that the value structures might be different at the individual and society levels (Hofstede, 2001; Schwartz, 1994), although there are opposing views as well (Fisher \& Poortinga, 2012). However, for describing or measuring the value dimensions at both levels often the same indicators (survey questions) are used (see, for example, Schwartz, 2011). Also, when it comes to the relationship of personal-level values and cultural values with some phenomenon, such as social capital, the mechanisms behind these relationships are often similar. For example, it can be expected that people with more fatalistic values, accepting authority and being modest, are less prone to actively engage in social processes. Similarly, people avoiding risks and valuing security can be assumed to be less trusting and thus also less cooperating. People valuing tolerance and solidarity can be supposed to be more prone to trust and cooperate than those valuing their own success and achievement. Also, people who value independence can be expected to be more socially active, while people who value loyalty might be more relying on the group and end up being less socially active.

The main question is whether the attitudes and actions of individuals are more influenced by their own values or the values dominating in the society. This is more relevant and apparent in cases where the personal values of individuals contradict the cultural values in the society around the individual in some way: for example, if a person who values independence highly happens to live in a generally collectivist society. As it can be assumed that there is a considerable variation among individuals in a society regarding values, it might be expected that it is not rare when personal values of individuals do not coincide with the cultural values of the society. Therefore, it is important to include both personal values and cultural values in the analysis of the individual-level social capital.

One important aspect related to culture and values is religion. Religion and religiosity are sometimes also viewed as a part of culture (Kaasa, 2015). However, there is no consensus here as religion has also 
been viewed as a source of culture (Schwartz, 2009; Aldashev \& Platteau, 2014) or as being caused by culture (Reimer, 1995; Hofstede, 1997). Hence, in this article religion is viewed as a separate, although an important factor of social capital. Kaasa (2013) provides an exhaustive overview of the literature about the impact of religion and religiosity on social capital. Previous studies have shown religiosity - promoting cooperation with and positive attitudes towards others - being positively related to social capital at both the individual and society levels (Halman \& Luijkx, 2006; Radnitz et al., 2009; Berggren \& Bjørnskov, 2011; Kaasa, 2013). However, it has been shown that if the individual-level religiosity is included, in most cases the society-level religiosity appears to be insignificant for individuals' social capital (Halman \& Luijkx, 2006; Kaasa, 2013). Regarding different denominations, it can be assumed that belonging to hierarchic religions (Catholicism, Orthodoxy, Islam) is negatively and to non-hierarchic religions (Protestantism, Hinduism, Buddhism, etc.) positively related to social capital. The reasoning, however, is very similar to the one described before when discussing the impact of power distance: hierarchic religions are expected to impose a hierarchic structure on society and people are assumed to have a more fatalistic mentality, rather passively relying on the government to take responsibility (Knack \& Keefer, 1997; La Porta et al., 1997; Lam, 2006; Kaasa 2013). Also, it has been argued that in the case of Protestantism individualist attitudes prevail, leading people to actively engage in social processes (Lam, 2006) - a reasoning that is related to individualist values. Hence, similarly to having the communist past, it is questionable whether religious denominations have an impact per se or if the described mechanism of the determination of social capital can be captured with personal values or cultural dimensions. The societylevel analysis of Kaasa (2015) showed that after including culture into the analysis, religiosity and the share of hierarchic religion in a society remained significant only for general trust and not for the other dimensions of social capital.

\section{DATA AND METHODOLOGY}

The individual-level data describing social capital and its individual-level determinants were drawn from the European Social Survey (2008), a biennial multi-country survey with 1,500-2,500 respondents per country. As the survey includes information about within-country regions as well, it enables to include within-country regions (NUTS1 regions) as society-level units in order to increase the society-level sample. The NUTS - nomenclature of territorial units for statistics - is a hierarchic classification of regions within countries established by Eurostat (see Eurostat, 2012). The number of respondents per region at the NUTS1 level was 545.74 on average and ranged from 21 to 2,367. The number of respondents was quite low in some regions and to ensure that the data would be representative of the demographic structure of a region, the weights provided by the ESS were applied. Data from the year 2008 were chosen to be in accordance with the data availability about cultural dimensions.

Regarding social capital, for operationalising general trust, institutional trust and civic participation, three indicators were used for each, but only two indicators could be used for describing informal networks. Unfortunately, there were no indicators available reflecting formal networks. In order to describe religiosity, four indicators were used. The list of indicators used in this study is given in Appendix Table A1. The information about the initial indicators was captured into factors of social capital and religiosity with the help of confirmatory factor analysis (principal components method). Because of some missing values in the data set, here and hereafter cases were excluded pair-wise, not list-wise, in order to utilise all the information available. The factor loadings, percentages of total variance explained by the factors, and the Kaiser-Meyer-Olkin (KMO) measures indicating the appropriateness of the factor model are presented in Appendix Table A2. The share of the total variance explained and the KMO measure can 
be viewed as acceptable (in the case of only two indicators, the KMO value is always 0.5 because of the formula used for calculating the KMO measure). The factor scores were saved as variables.

In order to test the relationship between social capital and personal values, eight questions (see Appendix Table A1) were chosen from the 21 Schwartz value items included in the ESS. A similar approach was used by Halman and Luijkx (2006) who chose the indicators for their factors of individualism and moral sense from the same set of questions. In this article, the choice of indicators was made aiming to cover different aspects that were mentioned in the theoretical background section. The possible fatalistic and authority-accepting values are covered with questions about the importance of a strong government and the importance of being humble and modest. The values related to security and avoiding uncertain situations are described with questions about the importance of safety and secure surroundings and the importance of adventures and taking risks. Tolerance and solidarity are described by the question about the importance of understanding different people, while the opposite values are described by the question about the importance of achievements and being successful. Valuing rather independence or belonging is covered by the questions about the importance of independence and making own decisions and the importance of loyalty and devotion.

In addition, individual-level control variables describing age, gender, education, income, the size of the domicile, living with a partner, and employment status were included. The selections were made in order to offer the best possible comparability with earlier studies (Fidrmuc \& Gërxhani, 2005; van Oorschot et al., 2006; Kaasa \& Parts, 2008; Christoforou, 2011) considering data availability.

Regarding the regional level, the indicators of Hofstede's cultural dimensions came from Kaasa et al. (2014) who created new indicators for measuring Hofstede's original dimensions using the data from the ESS and the European Values Survey (EVS, 2008) for the year 2008 when both surveys were conducted. Every dimension was created with the help of confirmatory factor analysis from six initial indicators from both the ESS and EVS aggregated to the regional level (Kaasa et al., 2014). The choice of indicators was theory-based rather than empirically-driven in order to ensure that the new indicators of cultural dimensions would conceptually represent the same dimensions as in Hofstede (1980, 2001).

The general religiosity of a region was calculated as a mean value of the respondents in that particular region. As the factor structure might turn out to be different at the regional level and at the individual level, a similar factor analysis was performed on the aggregated initial religiosity indicators, but the resulting factor was correlated with the mean of the individual-level religiosity with the correlation coefficient equal to 0.99 (significant at the 0.01 level). The share of the population belonging to a hierarchic religion was approximated based on the data of the respondents in that particular region. As control variables, also the GDP per capita in purchasing power standards (PPS) stemming from Eurostat (2018) and the variable reflecting the communist background were included. Unfortunately, data about other society-level control variables such as income inequality, for instance, that have been used in previous studies, (van Oorschot \& Arts, 2005; Fidrmuc \& Gërxhani, 2005; Kaasa, 2013) were not available at the regional level.

The number of regions covered in this analysis was limited by the coverage in the ESS as well as the number of regions for which the regional-level data were available. In all, data of 56,752 respondents in 85 regions were analysed. The 25 countries included in this way are Belgium, Bulgaria, Croatia, the Czech Republic, Cyprus, Denmark, Estonia, Finland, France, Germany, Greece, Hungary, Ireland, Latvia, the Netherlands, Norway, Poland, Portugal, Romania, Slovakia, Slovenia, Spain, Sweden, Switzerland, and the United Kingdom.

Multilevel regression analysis was used in order to take into account the hierarchic data structure. Models with random intercepts are presented in Tables 1-4. Models with random slopes were analysed as well and they gave very similar results, the information criteria did not improve remarkably and random 
effects were close to zero at the 0.01 level. In order to examine potential multicollinearity, variance inflation factors (VIF) were calculated for all models and they were all below the conventional level of 10 .

Multilevel regression analysis was performed on four sets of models, one on each dimension of social capital. First, only individual-level control variables were included in the analysis. As the coefficients of the individual-level control variables were very stable and the results did not differ from the following models, this setup is not presented in Tables 1-4. Then, the regional-level control variables were added (Model 1). After that, personal values were added (Model 2). A model with only individual-level controls and personal values (without regional-level controls) was tested as well. However, as the coefficients of the variables describing personal values proved to be very stable throughout all models as well, this setup was also omitted from Tables 1-4. In order to test whether the variables describing personal values might explain the same part of the variation in social capital as religiosity or belonging to a hierarchic religion, the analysis was also performed excluding individual-level religiosity and hierarchic religion while keeping personal values. The coefficients of the variables describing personal values, however, did not change. Next, cultural dimensions were added to all control variables, excluding personal values at the same time personal values (Model 3). Then, all independent variables were included (Model 4). In order to investigate whether cultural dimensions could capture some part of the impact of the communist background, a model excluding the communist background variable was estimated (Model 5). For similar reasons, in another model general religiosity and the share of hierarchic religion were left out (Model 6). Expectedly, the models were improved according to the information criteria by adding variable groups, but the improvement was more remarkable after adding regional-level variables.

\section{RESULTS}

The results of the multilevel regression analysis are presented in Tables 1-4. Regarding the individuallevel controls, coefficients were very stable and all the coefficients had the expected signs, confirming the results of previous studies. Regarding the relative importance, for general trust education and income turned out to be the most important, while for institutional trust religiosity was even more relevant than education and income. Education appeared to be crucial for civic participation as well, while the level of informal networks turned out to be remarkably explainable by age: younger people tend to have more informal networks.

Among the regional-level controls, GDP appeared to be statistically significant only for the cognitive dimensions of social capital (general and institutional trust) and for institutional trust only until the cultural dimensions were added to the model, thus indicating the tendency also shown by Kaasa (2015). The same applies to general religiosity in the case of the structural dimensions of social capital (informal networks and civic participation). The share of those belonging to hierarchic religions was also not relevant for informal networks and civic participation. In the case of general and institutional trust, both religiosity and hierarchic religion were significant after adding cultural dimensions. Hence, the religion-related context seems to be more relevant for the cognitive social capital of individuals than the structural social capital it can be said that religiosity and the imprint of a hierarchic religion in a society influence attitudes rather than actions. When the religion-related context was left out from the models, the coefficients of cultural dimensions appeared to "take over" the effect of the religious context to some extent, but there were no drastic changes in the results regarding culture. Communist background turned out not to be significant for general trust and informal networks after adding cultural dimensions into the analysis. 
Table 1

Estimation results of Multilevel Random Intercepts and Random Slopes Model (standardised coefficients) for General trust

\begin{tabular}{|c|c|c|c|c|c|c|}
\hline Fixed effects: & Model 1 & Model 2 & Model 3 & Model 4 & Model 5 & Model 6 \\
\hline \multicolumn{7}{|l|}{ Individual level: } \\
\hline Intercept & -0.04 & $-0.05^{*}$ & -0.03 & -0.03 & $-0.04 *$ & -0.03 \\
\hline Age & $0.05^{* * *}$ & $0.06^{* * *}$ & $0.05^{* * *}$ & $0.06^{* * *}$ & $0.06^{* * *}$ & $0.06^{* * *}$ \\
\hline Gender & $-0.02 * * *$ & $-0.02 * * *$ & $-0.02 * * *$ & $-0.02 * * *$ & $-0.02 * * *$ & $-0.02 * * *$ \\
\hline Education & $0.09 * * *$ & $0.08^{* * *}$ & $0.09^{* * *}$ & $0.08^{* * *}$ & $0.08^{* * *}$ & $0.08^{* * *}$ \\
\hline Income & $0.08^{* * *}$ & $0.08^{* * *}$ & $0.08^{* * *}$ & $0.08^{* * *}$ & $0.08^{* * *}$ & $0.08 * * *$ \\
\hline Domicile size & -0.01 & -0.01 & -0.01 & -0.01 & -0.01 & -0.01 \\
\hline Living with partner & -0.01 & -0.01 & -0.01 & -0.01 & -0.01 & -0.01 \\
\hline Employment & 0.01 & 0.00 & 0.01 & 0.00 & 0.00 & 0.00 \\
\hline Religiosity & $0.06^{* * *}$ & $0.06^{* * *}$ & $0.06^{* * *}$ & $0.06^{* * *}$ & $0.06^{* * *}$ & $0.06^{* * *}$ \\
\hline Hierarchic religion & $-0.03 * * *$ & $-0.02 * * *$ & $-0.03 * * *$ & $-0.02^{* * *}$ & $-0.02^{* * *}$ & $-0.02^{* * *}$ \\
\hline Strong government & & $-0.04 * * *$ & & $-0.04 * * *$ & $-0.04^{* * *}$ & $-0.04 * * *$ \\
\hline Being modest & & $-0.02 * * *$ & & $-0.02 * * *$ & $-0.02 * * *$ & $-0.02 * * *$ \\
\hline Secure surroundings & & $-0.05^{* * *}$ & & $-0.05^{* * *}$ & $-0.05^{* * *}$ & $-0.05^{* * *}$ \\
\hline Taking risks & & 0.00 & & 0.00 & 0.00 & 0.00 \\
\hline Achievement & & 0.00 & & 0.00 & 0.00 & 0.00 \\
\hline Understanding people & & $0.04^{* * *}$ & & $0.04 * * *$ & $0.04 * * *$ & $0.04 * * *$ \\
\hline Independence & & $-0.02 * * *$ & & $-0.02 * * *$ & $-0.02 * * *$ & $-0.02 * * *$ \\
\hline Loyalty & & $0.04 * * *$ & & $0.04 * * *$ & $0.04 * * *$ & $0.04 * * *$ \\
\hline \multicolumn{7}{|l|}{ Regional level: } \\
\hline GDP & $0.11 * * *$ & $0.11 * * *$ & $0.06^{*}$ & $0.07 * *$ & $0.06^{* *}$ & $0.05^{* *}$ \\
\hline General religiosity & 0.05 & 0.05 & $0.12 * *$ & $0.12 * *$ & $0.12 * *$ & \\
\hline Share of hier. religion & $-0.28 * * *$ & $-0.28 * * *$ & $-0.24 * * *$ & $-0.24 * * *$ & $-0.25 * * *$ & \\
\hline Communist background & $-0.07 *$ & -0.06 & 0.04 & 0.05 & & 0.06 \\
\hline Power distance & & & $-0.20 * * *$ & $-0.20 * * *$ & $-0.18 * * *$ & $-0.25 * * *$ \\
\hline Uncertainty avoidance & & & $0.07 *$ & $0.10 * * *$ & $0.10 * * *$ & $0.06^{* * *}$ \\
\hline Masculinity & & & $-0.18 * * *$ & $-0.18 * * *$ & $-0.16 * * *$ & $-0.21 * * *$ \\
\hline Individualism & & & 0.00 & -0.01 & -0.02 & 0.03 \\
\hline \multicolumn{7}{|l|}{ Random effects: } \\
\hline Residuals & $0.72^{* * *}$ & $0.71 * * *$ & $0.72^{* * *}$ & $0.71^{* * *}$ & $0.71^{* * *}$ & $0.71 * * *$ \\
\hline Intercept & $0.04 * * *$ & $0.04 * * *$ & $0.02^{* * *}$ & $0.02 * * *$ & $0.02^{* * *}$ & $0.04 * * *$ \\
\hline \multicolumn{7}{|l|}{ Information Criteria } \\
\hline -2 Restricted Log Likelihood & 77029.58 & 76771.09 & 77000.00 & 76745.05 & 76742.02 & 76770.84 \\
\hline $\begin{array}{l}\text { Akaike's Information } \\
\text { Criterion (AIC) }\end{array}$ & 77033.58 & 76775.09 & 77004.00 & 76749.05 & 76746.02 & 76774.84 \\
\hline $\begin{array}{l}\text { Schwarz's Bayesian Criterion } \\
\text { (BIC) }\end{array}$ & 77050.24 & 76791.75 & 77020.66 & 76765.71 & 76762.68 & 76791.50 \\
\hline
\end{tabular}

*** significant at the 0.01 level, ${ }^{* *}$ significant at the 0.05 level, * significant at the 0.10 level

Bold is used for highlighting coefficients larger than or equal to 0.10 . 
Table 2

Estimation results of Multilevel Random Intercepts and Random Slopes Model (standardised coefficients) for Institutional trust

\begin{tabular}{|c|c|c|c|c|c|c|}
\hline Fixed effects: & Model 1 & Model 2 & Model 3 & Model 4 & Model 5 & Model 6 \\
\hline \multicolumn{7}{|l|}{ Individual level: } \\
\hline Intercept & -0.02 & -0.02 & 0.00 & 0.00 & 0.01 & 0.00 \\
\hline Age & 0.00 & 0.00 & 0.00 & 0.00 & 0.00 & 0.00 \\
\hline Gender & $0.02 * * *$ & $0.02 * * *$ & $0.02 * * *$ & $0.02 * * *$ & $0.02 * * *$ & $0.02 * * *$ \\
\hline Education & $0.07 * * *$ & $0.07 * * *$ & $0.07 * * *$ & $0.07 * * *$ & $0.07 * * *$ & $0.07 * * *$ \\
\hline Income & $0.08^{* * *}$ & $0.08^{* * *}$ & $0.08^{* * *}$ & $0.08^{* * *}$ & $0.08^{* * *}$ & $0.08^{* * *}$ \\
\hline Domicile size & 0.00 & 0.00 & 0.00 & 0.00 & 0.00 & 0.00 \\
\hline Living with partner & $-0.02 * * *$ & $-0.02 * * *$ & $-0.02 * * *$ & $-0.02 * * *$ & $-0.02 * * *$ & $-0.02 * * *$ \\
\hline Employment & $0.02 * * *$ & $0.02 * * *$ & $0.02 * * *$ & $0.01 * * *$ & $0.01 * * *$ & $0.01 * * *$ \\
\hline Religiosity & $0.11 * * *$ & $0.11 * * *$ & $0.11 * * *$ & $0.11 * * *$ & $0.11 * * *$ & $0.11 * * *$ \\
\hline Hierarchic religion & -0.01 & -0.01 & -0.01 & -0.01 & -0.01 & -0.01 \\
\hline Strong government & & 0.00 & & 0.00 & 0.00 & 0.00 \\
\hline Being modest & & -0.01 & & -0.01 & -0.01 & -0.01 \\
\hline Secure surroundings & & -0.01 & & -0.01 & -0.01 & -0.01 \\
\hline Taking risks & & $-0.04 * * *$ & & $-0.04 * * *$ & $-0.04 * * *$ & $-0.04 * * *$ \\
\hline Achievement & & $0.02 * * *$ & & $0.02 * * *$ & $0.02^{* * *}$ & $0.02^{* * *}$ \\
\hline Understanding people & & $0.03^{* * *}$ & & $0.03^{* * *}$ & $0.03^{* * *}$ & $0.03^{* * *}$ \\
\hline Independence & & $-0.04 * * *$ & & $-0.04^{* * *}$ & $-0.04^{* * *}$ & $-0.04 * * *$ \\
\hline Loyalty & & 0.01 & & 0.01 & 0.01 & 0.01 \\
\hline \multicolumn{7}{|l|}{ Regional level: } \\
\hline GDP & $0.11 * * *$ & $0.11 * * *$ & 0.00 & 0.00 & 0.02 & -0.01 \\
\hline General religiosity & $0.09 *$ & $0.09 * *$ & $0.07 *$ & $0.08^{*}$ & $0.08^{*}$ & \\
\hline Share of hier. religion & $-0.22 * * *$ & $-0.23 * * *$ & $-0.13 * * *$ & $-0.14 * * *$ & $-0.13 * * *$ & \\
\hline Communist background & $-0.19 * * *$ & $-0.19 * * *$ & $-0.09 * * *$ & $-0.09 * * *$ & & $-0.08^{* * *}$ \\
\hline Power distance & & & $-0.24 * * *$ & $-0.24 * * *$ & $-0.28 * * *$ & $-0.28 * * *$ \\
\hline Uncertainty avoidance & & & -0.01 & -0.01 & 0.01 & -0.03 \\
\hline Masculinity & & & -0.06 & -0.06 & $-0.09^{* * *}$ & -0.06 \\
\hline Individualism & & & 0.03 & 0.03 & $0.05^{*}$ & 0.05 \\
\hline \multicolumn{7}{|l|}{ Random effects: } \\
\hline Residuals & $0.67^{* * *}$ & $0.68^{* * *}$ & $0.68^{* * *}$ & $0.68^{* * *}$ & $0.67^{* * *}$ & $0.67 * * *$ \\
\hline Intercept & $0.04 * * *$ & $0.04 * * *$ & $0.02^{* * *}$ & $0.02^{* * *}$ & $0.02 * * *$ & $0.02^{* * *}$ \\
\hline \multicolumn{7}{|l|}{ Information Criteria } \\
\hline -2 Restricted Log Likelihood & 73582.53 & 73528.97 & 73554.84 & 73500.31 & 73503.16 & 73504.48 \\
\hline $\begin{array}{l}\text { Akaike's Information } \\
\text { Criterion (AIC) } \\
\end{array}$ & 73586.53 & 73532.97 & 73558.84 & 73504.31 & 73507.16 & 73508.48 \\
\hline $\begin{array}{l}\text { Schwarz's Bayesian Criterion } \\
\text { (BIC) }\end{array}$ & 73603.15 & 73549.58 & 73575.45 & 73520.92 & 735203.77 & 73525.09 \\
\hline
\end{tabular}

*** significant at the 0.01 level, ** significant at the 0.05 level, * significant at the 0.10 level

Bold is used for highlighting coefficients larger than or equal to 0.10 . 
Table 3

Estimation results of Multilevel Random Intercepts and Random Slopes Model (standardised coefficients) for Informal networks

\begin{tabular}{|c|c|c|c|c|c|c|}
\hline Fixed effects: & Model 1 & Model 2 & Model 3 & Model 4 & Model 5 & Model 6 \\
\hline \multicolumn{7}{|l|}{ Individual level: } \\
\hline Intercept & $-0.06 * *$ & $-0.07 * * *$ & $0.06 * * *$ & $0.07 * * *$ & $-0.06 * * *$ & $0.07 * * *$ \\
\hline Age & $-0.24 * * *$ & $-0.22 * * *$ & $-0.24 * * *$ & $-0.22 * * *$ & $-0.22 * * *$ & $-0.22 * * *$ \\
\hline Gender & $-0.02 * * *$ & $-0.02 * * *$ & $-0.02 * * *$ & $-0.02 * * *$ & $-0.02 * * *$ & $-0.02 * * *$ \\
\hline Education & $0.04^{* * *}$ & $0.03^{* * *}$ & $0.04^{* * *}$ & $0.02^{* * *}$ & $0.02^{* * *}$ & $0.02 * * *$ \\
\hline Income & $0.07 * * *$ & $0.06^{* * *}$ & $0.07 * * *$ & $0.06^{* * *}$ & $0.06^{* * *}$ & $0.06^{* * *}$ \\
\hline Domicile size & $0.02 * * *$ & $0.02 * * *$ & $0.02 * * *$ & $0.02 * * *$ & $0.02 * * *$ & $0.02 * * *$ \\
\hline Living with partner & $-0.03 * * *$ & $-0.02 * * *$ & $-0.03 * * *$ & $-0.02 * * *$ & $-0.02 * * *$ & $-0.02 * * *$ \\
\hline Employment & $-0.02 * * *$ & $-0.02 * * *$ & $-0.02 * * *$ & $-0.02 * * *$ & $-0.02 * * *$ & $-0.02 * * *$ \\
\hline Religiosity & $0.06^{* * *}$ & $0.06^{* * *}$ & $0.06^{* * *}$ & $0.06^{* * *}$ & $0.06 * * *$ & $0.06 * * *$ \\
\hline Hierarchic religion & $-0.02^{* * *}$ & $-0.02^{* *}$ & $-0.02 * * *$ & $-0.02 * * *$ & $-0.02 * * *$ & $-0.02 * * *$ \\
\hline Strong government & & $-0.03 * * *$ & & $-0.03 * * *$ & $-0.03 * * *$ & $-0.03 * * *$ \\
\hline Being modest & & $-0.03 * * *$ & & $-0.03^{* * *}$ & $-0.03 * * *$ & $-0.03 * * *$ \\
\hline Secure surroundings & & $-0.02 * * *$ & & $-0.02 * * *$ & $-0.02 * * *$ & $-0.02 * * *$ \\
\hline Taking risks & & $0.04^{* * *}$ & & $0.04^{* * *}$ & $0.04^{* * *}$ & $0.04^{* * *}$ \\
\hline Achievement & & 0.00 & & 0.00 & 0.00 & 0.00 \\
\hline Understanding people & & $0.03^{* * *}$ & & $0.03 * * *$ & $0.03 * * *$ & $0.03 * * *$ \\
\hline Independence & & $0.01 * *$ & & $0.01 * *$ & $0.01 * *$ & $0.01 * *$ \\
\hline Loyalty & & $0.10 * * *$ & & $0.10 * * *$ & $0.10 * * *$ & $0.10 * * *$ \\
\hline \multicolumn{7}{|l|}{ Regional level: } \\
\hline GDP & 0.05 & 0.05 & 0.01 & 0.01 & 0.02 & 0.01 \\
\hline General religiosity & $-0.09 * *$ & $-0.10 * *$ & 0.02 & 0.01 & 0.01 & \\
\hline Share of hier. religion & 0.01 & 0.02 & 0.03 & 0.03 & 0.03 & \\
\hline Communist background & $-0.17 * * *$ & $-0.15 * * *$ & -0.05 & -0.04 & & -0.04 \\
\hline Power distance & & & $-0.16 * * *$ & $-0.15 * * *$ & $-0.16 * * *$ & $-0.15 * * *$ \\
\hline Uncertainty avoidance & & & $0.07 * *$ & $0.08^{* *}$ & $0.09 * *$ & $0.10 * * *$ \\
\hline Masculinity & & & $-0.24 * * *$ & $-0.23 * * *$ & $-0.24 * * *$ & $-0.20 * * *$ \\
\hline Individualism & & & $0.05^{*}$ & 0.04 & 0.05 & 0.02 \\
\hline \multicolumn{7}{|l|}{ Random effects: } \\
\hline Residuals & $0.82 * * *$ & $0.81 * * *$ & $0.82^{* * *}$ & $0.81 * * *$ & $0.81 * * *$ & $0.81 * * *$ \\
\hline Intercept & $0.04 * * *$ & $0.04 * * *$ & $0.02 * * *$ & $0.02 * * *$ & $0.02 * * *$ & $0.02 * * *$ \\
\hline \multicolumn{7}{|l|}{ Information Criteria } \\
\hline -2 Restricted Log Likelihood & 81016.15 & 80655.30 & 80984.50 & 80625.30 & 80621.65 & 80617.45 \\
\hline $\begin{array}{l}\text { Akaike's Information } \\
\text { Criterion (AIC) }\end{array}$ & 81020.15 & 80659.30 & 80988.50 & 80629.30 & 80625.65 & 80621.45 \\
\hline $\begin{array}{l}\text { Schwarz's Bayesian Criterion } \\
\text { (BIC) }\end{array}$ & 81036.81 & 80675.96 & 81005.16 & 80645.95 & 80642.31 & 80638.11 \\
\hline
\end{tabular}

*** significant at the 0.01 level, ** significant at the 0.05 level, * significant at the 0.10 level

Bold is used for highlighting coefficients larger than or equal to 0.10 . 
Table 4

Estimation results of Multilevel Random Intercepts and Random Slopes Model (standardised coefficients) for Civic participation

\begin{tabular}{|c|c|c|c|c|c|c|}
\hline Fixed effects: & Model 1 & Model 2 & Model 3 & Model 4 & Model 5 & Model 6 \\
\hline \multicolumn{7}{|l|}{ Individual level: } \\
\hline Intercept & 0.03 & 0.02 & 0.01 & 0.00 & 0.03 & 0.00 \\
\hline Age & $-0.04 * * *$ & $-0.02 * * *$ & $-0.04 * * *$ & $-0.02^{* * *}$ & $-0.02 * * *$ & $-0.02 * * *$ \\
\hline Gender & $-0.03 * * *$ & $-0.03 * * *$ & $-0.03 * * *$ & $-0.03 * * *$ & $-0.03 * * *$ & $-0.03 * * *$ \\
\hline Education & $0.19 * * *$ & $0.17 * * *$ & $0.19 * * *$ & $0.17 * * *$ & $0.17 * * *$ & $0.17 * * *$ \\
\hline Income & $0.05^{* * *}$ & $0.05^{* * *}$ & $0.05^{* * *}$ & $0.05^{* * *}$ & $0.05^{* * *}$ & $0.05^{* * *}$ \\
\hline Domicile size & $0.05^{* * *}$ & $0.05^{* * *}$ & $0.05^{* * *}$ & $0.05^{* * *}$ & $0.05^{* * *}$ & $0.05^{* * *}$ \\
\hline Living with partner & 0.00 & 0.01 & 0.00 & 0.01 & 0.01 & 0.01 \\
\hline Employment & $0.01 * *$ & $0.01 * *$ & $0.01 * *$ & $0.01^{* *}$ & $0.01 * *$ & $0.01^{* *}$ \\
\hline Religiosity & $0.01 *$ & $0.02^{* * *}$ & $0.01 *$ & $0.02^{* * *}$ & $0.02^{* * *}$ & $0.02^{* * *}$ \\
\hline Hierarchic religion & $-0.05^{* * *}$ & $-0.04 * * *$ & $-0.05^{* * *}$ & $-0.04 * * *$ & $-0.04 * * *$ & $-0.04 * * *$ \\
\hline Strong government & & $-0.03 * * *$ & & $-0.02 * * *$ & $-0.02^{* * *}$ & $-0.02 * * *$ \\
\hline Being modest & & $-0.06^{* * *}$ & & $-0.06^{* * *}$ & $-0.06 * * *$ & $-0.06^{* * *}$ \\
\hline Secure surroundings & & $-0.08 * * *$ & & $-0.08^{* * *}$ & $-0.08^{* * *}$ & $-0.08 * * *$ \\
\hline Taking risks & & $0.04^{* * *}$ & & $0.04^{* * *}$ & $0.04^{* * *}$ & $0.04 * * *$ \\
\hline Achievement & & $-0.04 * * *$ & & $-0.04 * * *$ & $-0.04 * * *$ & $-0.04 * * *$ \\
\hline Understanding people & & $0.08^{* * *}$ & & $0.08^{* * *}$ & $0.08^{* * *}$ & $0.08^{* * *}$ \\
\hline Independence & & $0.05^{* * *}$ & & $0.05^{* * *}$ & $0.05^{* * *}$ & $0.05^{* * *}$ \\
\hline Loyalty & & $0.04 * * *$ & & $0.04^{* * *}$ & $0.04^{* * *}$ & $0.04^{* * *}$ \\
\hline \multicolumn{7}{|l|}{ Regional level: } \\
\hline GDP & 0.01 & 0.01 & -0.03 & -0.02 & 0.01 & -0.02 \\
\hline General religiosity & $-0.10 * *$ & $-0.11 * * *$ & 0.01 & -0.01 & -0.02 & \\
\hline Share of hier. religion & 0.01 & 0.02 & 0.01 & 0.02 & 0.04 & \\
\hline Communist background & $-0.20 * * *$ & $-0.17 * * *$ & $-0.17 * * *$ & $-0.15 * * *$ & & $-0.15 * * *$ \\
\hline Power distance & & & 0.03 & 0.04 & -0.03 & 0.05 \\
\hline Uncertainty avoidance & & & $-0.11 * *$ & $-0.08^{*}$ & -0.05 & $-0.08^{*}$ \\
\hline Masculinity & & & $-0.13 * * *$ & $-0.13 * * *$ & $-0.18 * * *$ & $-0.13 * * *$ \\
\hline Individualism & & & 0.03 & 0.01 & 0.05 & 0.01 \\
\hline \multicolumn{7}{|l|}{ Random effects: } \\
\hline Residuals & $0.95^{* * *}$ & $0.93^{* * *}$ & $0.95^{* * *}$ & $0.93^{* * *}$ & $0.93^{* * *}$ & $0.93^{* * *}$ \\
\hline Intercept & $0.04 * * *$ & $0.04 * * *$ & $0.03^{* * *}$ & $0.03^{* * *}$ & $0.04 * * *$ & $0.03^{* * *}$ \\
\hline \multicolumn{7}{|l|}{ Information Criteria } \\
\hline -2 Restricted Log Likelihood & 85622.40 & 85002.28 & 85615.67 & 85001.73 & 85012.24 & 84992.70 \\
\hline $\begin{array}{l}\text { Akaike's Information } \\
\text { Criterion (AIC) }\end{array}$ & 85626.40 & 85006.28 & 85619.67 & 85005.73 & 85016.24 & 84996.70 \\
\hline $\begin{array}{l}\text { Schwarz's Bayesian Criterion } \\
\text { (BIC) }\end{array}$ & 85643.06 & 85022.94 & 85626.33 & 85022.39 & 85032.90 & 85013.36 \\
\hline
\end{tabular}

*** significant at the 0.01 level, ** significant at the 0.05 level, * significant at the 0.10 level

Bold is used for highlighting coefficients larger than or equal to 0.10 . 
The negative coefficients of the communist background variable remained statistically significant for institutional trust and civic participation. Here, it seems that the communist background has an impact on those social capital dimensions that are related to the state, institutions and more formal and public social activities. It is logical that in these fields the communist past has left a stronger imprint. When the communist background was left out from the models, again the coefficients of cultural dimensions turned out to "take over" the effect of the communist past, but no drastic changes in the results appeared.

Regarding personal values, the variables describing fatalistic and authority accepting values turned out to be statistically significant for all social capital dimensions, except for institutional trust. The coefficients confirm the logic that these values lead people to wait for authorities to act rather than to be engaged themselves. However, this means that they should trust authorities, which is probably the mechanism that balances out the impact on institutional trust and explains the results concerning it. Similarly, the results show that except for institutional trust, valuing security is negatively and valuing taking risks positively related to social capital. In the case of institutional trust, security turned out to be insignificant (possibly for similar reasons as explained at the fatalistic and authority-accepting values) and taking risks had negative coefficients: people who avoid risks rather trust institutions. People valuing understanding different people tend to have a higher level of all social capital dimensions, showing that people valuing tolerance are indeed more prone to trust and cooperate. Valuing achievement and recognition turned out to be positively related to institutional trust - possibly those valuing recognition also tend to recognise institutions more - and negatively with civic participation, being in accordance with the results that demonstrated understanding different people being positively related to social capital. Regarding valuing independence and/or loyalty, the level of the cognitive dimensions of social capital tends to be lower when valuing independence, and general trust higher when valuing loyalty to friends. Expectedly, valuing loyalty is crucial for informal networks and for civic participation, apparently valuing both loyalty and independence are supporting values.

The coefficients turned out to have the highest absolute values for cultural dimensions. Power distance appeared to be negatively related to all dimensions of social capital except for civic participation, as expected. This confirms the assumption about the fatalistic view leading to less engagement and trust. It is possible that in the case of civic participation, the communist background captures similar characteristics of society as power distance. Masculinity appeared to be negatively related to all social capital dimensions, although in the case of institutional trust, the coefficients were not always statistically significant. This provides support to the assumption about a more feminine cultural context supporting social capital. The results concerning uncertainty avoidance are mixed. Uncertainty avoidance turned out to be negatively related to civic participation: people in generally uncertainty avoidant regions tend to be more careful and show less civic participation activities. At the same time, in regions with higher general uncertainty avoidance people tend to have more informal networks. This provides support for the assumption about informal relationships providing a buffer against uncertain situations. For institutional trust, it was not significant. It is possible here that the trust in institutions supposedly providing more security might balance out the negative impact. For general trust, the coefficients of uncertainty avoidance appeared to be negative. This might, however, be so because of a strong correlation in the sample analysed between power distance, uncertainty avoidance and masculinity. Although multicollinearity diagnostics did not indicate the need to leave some of the variables out, it is still possible that most of the social capital hindering effect was already captured by the power distance and masculinity variables and in this regression the coefficient of uncertainty avoidance describes the mechanism similarly to the one described at the informal networks. Somewhat surprisingly, but in accordance with the results of Kaasa (2015), individualism turned out to be insignificant in determining the social capital of individuals. It is possible that here the positive and negative influence mechanisms balance each other out. It is also worth 
mentioning that in the case of informal networks, values describing similar aspects at the individual level are very relevant.

\section{DISCUSSION}

The results of this article enable to shed light on what determines the level of social capital as an important factor of economic development. The results show that the cultural context is important not only for the general level of social capital in a society, but it also proves to be important in forming individuals' social capital besides individual-level determinants. However, the relative importance of various cultural dimensions may differ across social capital dimensions and furthermore, it may differ depending on the analysis level. Table 5 presents a comparison of the results of the current multilevel analysis with the regional-level analysis of Kaasa (2015). When comparing the results concerning cultural dimensions, it can be seen that there are less statistically significant coefficients in the current analysis, but all the coefficients that are still significant have the same sign as in Kaasa (2015). The only exception is the coefficient of uncertainty avoidance in the case of general trust which can possibly be explained with correlations between power distance, uncertainty avoidance and masculinity. Hence, when a society-level phenomenon has appeared to be statistically significantly related to the level of social capital in a society, it does not automatically imply that this society-level phenomenon is definitely statistically significantly related to the social capital of single individuals. Although the main directions of the relationships remain the same, it might well be that at the individual level these relationships do not manifest themselves so strongly and some other, possibly individual-level determinants, are much more important.

Regarding the relative importance of personal values and the cultural context, it can be seen from Tables 1-4 that the absolute values of statistically significant standardised coefficients are much bigger in the case of cultural dimensions than for the variables describing personal values. Even when taking into account that generally the aggregated level correlations tend to be stronger than the individual-level correlations (Ostroff, 1993), it seems that the cultural context is here more important than personal values. Social capital is a phenomenon that is strongly based on counteraction, reciprocity and cooperation: there need to be other actors whom to trust and with whom to form networks. Hence, it can be expected that the values, beliefs and practices that surround an individual in a society strongly influence the level of trust and the participation of a single individual. Furthermore, it might even be that this impact is relatively stronger than the impact of the personal values of this particular individual. It is hard, for example, for an individual to form networks even if he or she is in favour of social relationships and cooperation if the other members of the society would rather act on their own for some reason, for instance due to a historically developed custom in that society.

Regarding the communist past, the results of this study show that at least some of the impact that has been attributed to the communist past can actually be explained by the cultural context. However, it was not possible, at least with the cultural dimensions used in this analysis, to capture all the differences in social capital between the individuals living in the region with a communist past and the individuals in other regions. A result worth mentioning here is that the impact of the communist background that cannot be captured by cultural dimensions is mainly the impact on those social capital dimensions that are related to the state, institutions and more formal and public social activities: civic participation and institutional trust. As the communist regime itself was a phenomenon related to the state and institutions, it has an influence on people's attitudes towards institutions and how much they want to act as citizens and engage themselves in state affairs. 
Table 5

Comparison of the results with the results of Kaasa (2015)*

\begin{tabular}{|c|c|c|c|c|}
\hline & General trust & Institutional trust & Informal networks & Civic participation \\
\hline \multicolumn{5}{|l|}{$\begin{array}{l}\text { Kaasa } 2015 \\
\text { (regional level analysis): }\end{array}$} \\
\hline GDP & + & $(+)$ & $(+)$ & + \\
\hline General religiosity & + & & $(+)$ & $(-)$ \\
\hline Hierarchic religion & - & $(-)$ & $(-)$ & \\
\hline Communist background & - & $(-)$ & - & $(-)$ \\
\hline Power distance & - & - & - & \\
\hline Uncertainty avoidance & - & & + & - \\
\hline Masculinity & - & - & - & - \\
\hline Individualism & & + & & + \\
\hline \multicolumn{5}{|l|}{$\begin{array}{l}\text { Current analysis } \\
\text { (multilevel analysis): }\end{array}$} \\
\hline GDP & + & $(+)$ & & \\
\hline General religiosity & + & + & $(-)$ & $(-)$ \\
\hline Hierarchic religion & - & - & & \\
\hline Communist background & $(-)$ & - & $(-)$ & - \\
\hline Power distance & - & - & - & \\
\hline Uncertainty avoidance & + & & + & - \\
\hline Masculinity & - & & - & - \\
\hline Individualism & & & & \\
\hline
\end{tabular}

* "+” denotes a positive and "-“" a negative statistically significant regression coefficient, "(+)" and "(-)" correspond to positive and negative coefficients, respectively, that occurred only before adding culture into the model.

Regarding the religious context of a society, the results again indicate that at least some of the impact that might seem to belong to religion-related aspects can be captured by the cultural context. However, this strongly differs across social capital dimensions. For the structural dimensions of social capital, the coefficients of religiosity became insignificant after the cultural context was added, but it was not the case for cognitive dimensions. To discuss further the possible impact of general religiosity and the dominating religion in a society on the individuals' social capital, the results of this study show that both religiosity and the nature of the religion are relevant for the cognitive dimensions of social capital: people tend to have more general and institutional trust if they live in a region with a higher level of religiosity and a lower share of hierarchic religion. The structural dimensions at the same time turned out not to be affected by religion and religiosity. This implies that the character of certain social capital dimensions determines whether these dimensions can be expected to be influenced by religion and religiosity. The general and institutional trust of individuals that are more related to attitudes and feelings can be assumed to be affected by the dominating religions and the overall religiosity in a society. Civic participation and informal networks are more related to certain actions and are less related to the society's religious context. 


\section{CONCLUSION AND LIMITATIONS}

This article investigated personal values and the cultural background as possible factors of the individual-level social capital. As a novelty, both personal values and the cultural context were included into the multilevel regression analysis for various social capital dimensions. The individual-level data from the European Social Survey (ESS, 2008) pertaining to over 56,000 respondents from 85 regions were complemented with regional-level data from multiple sources.

The results show that the cultural context is indeed important in determining the level of individuals' social capital indicating the source of differences of the levels of social capital and hence, economic performance, in different regions. The strength and direction of the impact of different cultural dimensions, however, varies across different social capital dimensions. Nevertheless, although some relationships do not appear to be statistically significant in the individual-level analysis, the direction of relationships (positive or negative) remains the same irrespective of the analysis level. The results also imply that the cultural context is more important in determining the individual's social capital than personal values. The results also indicate that some of the supposed impact of the communist past or the religious context on the level of social capital can be captured and explained by the cultural dimensions. However, at least the cultural dimensions included in this study did not cover all the relationships of the communist past or the religious context and social capital.

There are several limitations that should be recognised with respect to this study. First, the data collected from regions in 25 European countries were used. Hence, conclusions can be drawn only for the regions analysed and the results might be different when more European countries or, moreover, countries from over the world would become available to study. Also, it was not possible to include formal networks as a dimension of social capital because there were no data available. In addition, the choice of control variables was limited by the data availability at the regional level, as the data about the control variables that are often used at the country level, e.g. income inequality, are not available at the regional level. Last, it would be interesting to repeat the analysis using some other sets of cultural dimensions if data became available. However, despite these limitations, this article shed some light on the relative importance of different determinants of the individual-level social capital indicating it as an interesting topic for further studies in future research.

\section{ACKNOWLEDGEMENT}

This work was supported by the institutional research funding IUT 20-49 and PUT PRG380 of the Estonian Research Council.

\section{REFERENCES}

Adler, P.S., \& Kwon, S.-W. (2002). Social capital: prospects for a new concept. Academy of Management Review, 27, 1740.

Aldashev, G., \& Platteau, J.-P. (2014). Religion, Culture, and Development. In Ginsburgh, V.A., Throsby, D. (Eds.) Handbook of the Economics of Art and Culture, 2, Elsevier, 587-631.

Allik, J., \& Realo, A. (2004). Individualism-Collectivism and Social Capital. Journal of Cross-Cultural Psychology, 35, 2949.

Berggren, N., \& Bjørnskov, C. (2011). Is the importance of religion in daily life related to social trust? Cross-country and cross-state comparisons. Journal of Economic Behavior \& Organization, 80, 459- 480.

Berry, H., \& Rickwood, D. (2000). Measuring Social Capital at the Individual Level: Personal Social Capital, Values and Psychological Distress. Journal of Public Mental Health, 2(3), 35-44. 
Beugelsdijk, S., van Schaik, T., \& Arts, W. (2006). Toward a unified Europe: explaining regional differences in value patterns by economic development, cultural heritage and historical shocks. Regional Studies, 40(3), 317-327.

Bjørnskov, C. (2006). Determinants of generalized trust: A cross-country comparison. Public Choice, 130, 1-21.

Bourdieu, P. (1986). The forms of capital. In Richardson, J.G. (Ed.). Handbook of Theory and Research for the Sociology of Education. Greenwood Press, New York, 241-258.

Chanchani, S., \& Theivanathampillai, P. (2002). Typologies of culture. University of Otago, Department of Accountancy and Business Law Working Papers Series, 04_10/02, University of Otago, Dunedin.

Chiang, F. (2005). A critical examination of Hofstede's thesis and its application to international reward management. International Journal of Human Resource Management, 16, 1545-1563.

Christoforou, A. (2011). Social Capital across European Countries Individual and Aggregate Determinants of Group Membership. American Journal of Economics and Sociology, 70, 699-728.

Coleman, J.S. (1988). Social capital in the creation of human capital. American Journal of Sociology, 94 (Suppl.), 95-120.

Drnakova, L. (2006). Cultural Values in Transition Environment - Assessment Based on International Social Survey Programme Data, CERGE-EI Discussion Papers, No. 159.

ESS (2008). ESS Round 4: European Social Survey Round 4 Data (2008). Data file edition 4.0. Norwegian Social Science Data Services, Norway - Data Archive and distributor of ESS data.

European Commission. Eurostat (2012). NUTS - Nomenclature of territorial units for statistics. Introduction. Retrieved from: http://epp.eurostat.ec.europa.eu/portal/page/portal/nuts_nomenclature/introduction (24.09.2013).

Eurostat (2018). Database. Retrieved from: http:/ /ec.europa.eu/eurostat/data/database (04.03.2018).

EVS (2008). European values study, 4th wave, integrated dataset, ZA4800 data file version 2.0.0 (2010-11-30). GESIS Data Archive, Cologne, doi:10.4232/1.10188.

Fidrmuc, J., \& Gërxhani, K. (2005). Formation of Social Capital in Central and Eastern Europe: Understanding the Gap Vis-a-Vis Developed Countries. William Davidson Institute Working Paper, No. 766.

Fischer, R., \& Poortinga, Y.H. (2012). Are cultural values the same as the values of individuals? An examination of similarities in personal, social and cultural value structures. International Journal of Cross Cultural Management, 12(2), 157-170.

Gooderham, P., \& Nordhaug, O. (2001). Are cultural differences in Europe on the decline?. European Business Forum, $8,48-53$.

Hall, S. (1980). Cultural studies: two paradigms. In Dirk, F.E.N.B, \& Ortner, S.B. (Eds). A reader in contemporary social theory, Princeton University Press, Princeton, NJ), 520-538.

Halman, L., \& Luijkx, R. (2006). Social capital in contemporary Europe: evidence from the European Social Survey. Portuguese Journal of Social Science, 5, 65-90.

Hjøllund, L., \& Svendsen, G.T., (2000). Social Capital: A Standard Method of Measurement. University of Aarbus Working Papers, No. 00-9, Aarhus School of Business, Department of Economics.

Hofstede, G. (1980). Culture's Consequences: International Differences in Work Related Values. Beverly Hills, CA: Sage Publications.

Hofstede, G. (1997). Cultures and Organizations: Software of the Mind, 1st edition, New York, McGraw-Hill USA.

Hofstede, G. (2001). Culture's Consequenses: Comparing Values, Behaviors, Institutions, and Organizations across Nations, 2nd ed., Sage Publications, Thousand Oaks, CA.

House, R., Javidan, M., Hanges, P., \& Dorfman, P. (2002). Understanding cultures and implicit leadership theories across the globe: an introduction to project GLOBE. Journal of World Business, 37(1), 3-10.

Inglehart, R., \& Baker, W.E. (2000). Modernization, Cultural Change, and the Persistence of Traditional Values. American Sociological Review, 65(1) Looking Forward, Looking Back: Continuity and Change at the Turn of the Millenium), 19-51.

Kaasa, A. (2013). Religion and social capital: evidence from European countries. International Review of Sociology, 23(3), $578-596$.

Kaasa, A. (2015). Culture, religion and social capital: evidence from European regions. International Journal of Sociology and Social Policy, 35(11/12), 772-794. 
Kaasa, A., \& Parts, E. (2008). Individual-level determinants of social capital in Europe: differences between country groups. Acta Sociologica, 51(2), 145-168.

Kaasa, A., Parts, E., \& Kaldaru, H. (2011). The Role of Human and Social Capital for Innovation in Catching-Up Economies. In Carayannis, E.G., Varblane, U., \& Roolaht, T. (eds) Innovation Systems in Small Catching-Up Economies: New Perspectives on Practice and Policy, Springer, New York, 259-276

Kaasa, A., Vadi, M., \& Varblane, U. (2013). European Social Survey as a source of new cultural dimensions estimates for regions. International Journal of Cross Cultural Management, 13(2), 137-157.

Kaasa, A., Vadi, M., \& Varblane, U. (2014). Regional Cultural Differences Within European Countries: Evidence from Multi-Country Surveys. Management International Review, available online, 54(6), 825-852.

Kluckhohn, F.R., \& Strodtbeck, F. (1961). V ariations in value orientations, Row, Peterson, Evanston, IL.

Knack, S., \& Keefer, P. (1997). Does Social Capital Have An Economic Payoff? A Cross-Country Investigation. The Quarterly Journal of Economics, 112, 1251-1288.

La Porta, R., Lopez-de-Silanes, F., Shleifer, A., \& Vishny, R. W. (1997). Trust in Large Organizations, The American Economic Review, 87, Papers and Proceedings of the Hundred and Fourth Annual Meeting of the American Economic, 333-338.

Lam, P.-Y. (2006). Religion and Civic Culture: A Cross-National Study of Voluntary Association Membership. Journal for the Scientific Study of Religion, 45, 177-193.

McSweeney, B. (2002). Hofstede's model of national cultural differences and their consequences: A triumph of faith - a failure of analysis. Human Relations, 55(1), 89-118.

Mondéjar-Jiménez, J., Mondéjar-Jiménez, J-A., Meseguer-Santamaría, M.-L., \& Vargas-Vargas, M. (2011). An empirical assessment of individual-level determinants of social capital in Central European countries. Journal for East European Management Studies, 16(3), 237-250.

Ostroff, C. (1993). Comparing Correlations Based on Individual-Level and Aggregated Data. Journal of Applied Psychology, 78(4), 569-582.

Oyserman, D., Coon, H.M., \& Kemmelmeier, M. (2002). Rethinking Individualism and Collectivism: Evaluation of Theoretical Assumptions and Meta-Analyses. Psychological Bulletin, 128(1), 3-72.

Parsons, T., \& Shils, E.A. (1951). Toward a general theory of action, Harvard University Press, Cambridge, MA.

Portes, A. (1998). Social capital: its origins and application in contemporary sociology. Annual Review of Sociology, 24, $1-24$.

Putnam, R. (1995). Bowling alone: Americas declining social capital. Journal of Democracy, 6, 65-78.

Radnitz, S. (2009). The Origins of Social Capital: Evidence From a Survey of Post-Soviet Central Asia. Comparative Political Studies, 42, 707-732.

Reimer, S.H. (1995). A Look at Cultural Effects on Religiosity: A Comparison between the United States and Canada. Journal for the Scientific Study of Religion, 34(4), 445-457.

Schwartz, S.H. (1994). Beyond individualism/collectivism: New cultural dimensions of values. In Kim, U., Triandis, H.C., Kagitçibasi, C.., Choi, S.C., \& Yoon, G. (Eds) Individualism and collectivism: Theory, method, and applications, Thousand Oaks, CA: Sage, 85-119.

Schwartz, S.H. (2009). Causes of culture: National differences in cultural embeddedness. In Gari, A., \& Mylonas, K. (Eds.). Quod Erat Demonstrandum. From Herodotus' ethnographic journeys to cross-cultural research, Pedio Books Publishing, Athens, 1-12.

Schwartz, S.H. (2011). Values: Cultural and Individual. In van de Vijver, F.J.R., Chasiotis, A., \& Breugelmans, S.M. (Eds) Fundamental questions in cross-cultural psychology, Cambridge: Cambridge University Press, 463-493.

Sztompka, P. (2000). The Ambivalence of Social Change: Triumph or Trauma?, Wissenschaftszentrum Berlin für Sozialforschung. Retrieved from: http://bibliothek.wzb.eu/pdf/2000/p00-001.pdf (05.12. 2011).

Tamaschke, L. (2003). The role of social capital in regional technological innovation: seeing both the wood and the trees. In Huysman, M., Wenger, E., Wulf, W. (Eds.) Communities and Technologies, Kluwer BV, Deventer.

Taras, V., Rowney, J., \& Steel, P. (2009). Half a century of measuring culture: Review of approaches, challenges, and limitations based on the analysis of 121 instruments for quantifying culture. Journal of International Management, 15, 357-373. 
Trompenaars, A., Hampden-Turner, C. (1997). Riding the waves of culture: understanding cultural diversity in business, London: Nicholas Brealey Publishing.

van Oorschot, W., Arts, W., \& Gelissen, J. (2006). Social Capital in Europe: Measurement and Social and Regional Distribution of a Multifaceted Phenomenon. Acta Sociologica, 49, 149-167.

van Oorshot, W., \& Arts, W. (2005). Social capital of European welfare states: the crowding out hypothesis revisited. Journal of European Social Policy, 15, 5-26. 


\section{APPENDIX}

Table A1

Indicators used in the analysis

\begin{tabular}{|c|c|c|c|}
\hline Variable & Description of indicator according to the source* and final coding & Mean & $\begin{array}{c}\text { St. } \\
\text { dev. }\end{array}$ \\
\hline \multicolumn{4}{|l|}{$\begin{array}{l}\text { Individual level } \\
\text { variables: }\end{array}$} \\
\hline \multicolumn{4}{|l|}{ Social capital } \\
\hline \multirow[t]{3}{*}{ General trust } & Most people can be trusted or you can't be too careful (scale 0-10) & 4.87 & 2.49 \\
\hline & Most people try to take advantage of you, or try to be fair (scale $0-10$ ) & 5.44 & 2.37 \\
\hline & $\begin{array}{l}\text { Most of the time people helpful or mostly looking out for themselves (scale } \\
0-10)\end{array}$ & 4.70 & 2.38 \\
\hline \multirow[t]{3}{*}{ Institutional trust } & Trust in country's parliament (scale $0-10)$ & 4.23 & 2.59 \\
\hline & Trust in the legal system (scale $0-10)$ & 4.88 & 2.67 \\
\hline & Trust in the police (scale $0-10)$ & 5.71 & 2.62 \\
\hline \multirow[t]{2}{*}{ Informal networks } & How often socially meet with friends, relatives or colleagues (scale 1-7) & 4.87 & 1.62 \\
\hline & Anyone to discuss intimate and personal matters with $(1=$ yes, $0=$ no $)$ & 0.89 & 0.31 \\
\hline \multirow[t]{3}{*}{ Civic participation } & Signed petition last 12 months $(1=$ yes, $0=$ no $)$ & 0.20 & 0.40 \\
\hline & Taken part in lawful public demonstration last 12 months $(1=$ yes, $0=$ no $)$ & 0.06 & 0.24 \\
\hline & Boycotted certain products last 12 months $(1=$ yes, $0=$ no $)$ & 0.14 & 0.35 \\
\hline \multicolumn{4}{|l|}{ Personal values: } \\
\hline Strong government & $\begin{array}{l}\text { Important that the government ensures safety against all threats and the } \\
\text { state is strong so it can defend its citizens (scale 1-6) }\end{array}$ & 4.74 & 1.19 \\
\hline Being modest & Important to be humble and modest and not to draw attention (scale 1-6) & 4.28 & 1.28 \\
\hline $\begin{array}{l}\text { Secure } \\
\text { surroundings }\end{array}$ & $\begin{array}{l}\text { Important to live in secure surroundings and avoid anything that might } \\
\text { endanger safety (scale 1-6) }\end{array}$ & 4.73 & 1.20 \\
\hline Taking risks & Important to seek adventures, take risks and have an exciting life (scale 1-6) & 3.10 & 1.49 \\
\hline Achievement & $\begin{array}{l}\text { Important to be very successful and people are recognizing achievements } \\
\text { (scale 1-6) }\end{array}$ & 3.95 & 1.36 \\
\hline $\begin{array}{l}\text { Understanding } \\
\text { people }\end{array}$ & Important to understand different people even when disagreeing (scale 1-6) & 4.61 & 1.07 \\
\hline Independence & $\begin{array}{l}\text { Important to make own decisions, to be free and not depend on others } \\
\text { (scale 1-6) }\end{array}$ & 4.77 & 1.11 \\
\hline Loyalty & Important to be loyal to friends and devote to people close (scale 1-6) & 5.01 & 0.94 \\
\hline
\end{tabular}

*ESS (2008), if not stated otherwise 
Table A1 (continued)

Indicators used in the analysis

\begin{tabular}{|c|c|c|c|}
\hline Variable & Description of indicator according to the source* and final coding & Mean & $\begin{array}{c}\text { St. } \\
\text { dev. }\end{array}$ \\
\hline \multicolumn{4}{|l|}{$\begin{array}{l}\text { Individual level control } \\
\text { variables: }\end{array}$} \\
\hline Age & Age (years) & 48.02 & 18.44 \\
\hline Gender & Gender $(1=$ male, $0=$ female $)$ & 0.46 & 0.50 \\
\hline Education & Years of full-time education completed (years) & 12.14 & 4.11 \\
\hline Income & Household's total net income, all sources (scale 1-10) & 5.48 & 2.77 \\
\hline Domicile size & Domicile size (scale 1-5, 5=big city, $1=$ countryside) & 3.13 & 1.25 \\
\hline Living with partner & Lives with husband/wife/partner at household grid $(1=$ yes, $0=$ no $)$ & 0.59 & 0.49 \\
\hline Employment & Main activity, last 7 days, paid work $(1=$ yes, $0=$ no $)$ & 0.48 & 0.50 \\
\hline \multirow[t]{4}{*}{ Religiosity } & Belonging to particular religion or denomination $(1=$ yes, $0=$ no $)$ & 0.63 & 0.48 \\
\hline & How religious are you (scale $0-10)$ & 4.78 & 3.00 \\
\hline & How often attend religious services apart from special occasions (scale 1-7) & 2.63 & 1.52 \\
\hline & How often pray apart from at religious services (scale 1-7) & 3.44 & 2.43 \\
\hline Hierarchic religion & $\begin{array}{l}\text { Belonging to a hierarchic religion (Roman Catholic, Eastern Orthodox or } \\
\text { Islamic) at present }(1=\text { yes, } 0=\text { no) }\end{array}$ & 0.46 & 0.50 \\
\hline \multicolumn{4}{|l|}{$\begin{array}{l}\text { Regional level } \\
\text { variables: }\end{array}$} \\
\hline \multicolumn{4}{|l|}{ Culture: } \\
\hline Power distance & $\begin{array}{l}\text { ESS-EVS based indicator of power distance (mean } 0 \text {, standard deviation } \\
1)^{* *}\end{array}$ & -0.19 & 0.98 \\
\hline $\begin{array}{l}\text { Uncertainty } \\
\text { avoidance }\end{array}$ & $\begin{array}{l}\text { ESS-EVS based indicator of uncertainty avoidance (mean } 0 \text {, standard } \\
\text { deviation } 1)^{* *}\end{array}$ & -0.07 & 1.01 \\
\hline Masculinity & ESS-EVS based indicator of masculinity (mean 0 , standard deviation 1 )** & -0.05 & 0.97 \\
\hline Individualism & ESS-EVS based indicator of individualism (mean 0 , standard deviation 1$)^{* *}$ & 0.16 & 0.79 \\
\hline \multicolumn{4}{|l|}{$\begin{array}{l}\text { Regional level control } \\
\text { variables: }\end{array}$} \\
\hline $\begin{array}{l}\text { Communist } \\
\text { background }\end{array}$ & communist background $=1$, other $=0$ & 0.37 & 0.48 \\
\hline GDP & GDP per capita in a region, PPS***, thousands & 25.62 & 10.23 \\
\hline General religiosity & mean values of the factor of religiosity in a region & 0.14 & 0.93 \\
\hline $\begin{array}{l}\text { Share of hierarchic } \\
\text { religion }\end{array}$ & $\begin{array}{l}\text { share of respondents belonging to a hierarchic religion (Roman Catholic, } \\
\text { Eastern Orthodox or Islamic) in a region }\end{array}$ & 0.48 & 0.32 \\
\hline
\end{tabular}

* ESS (2008), if not stated otherwise; ** Kaasa et al. (2014); *** Eurostat (2018) 
Table A2

Results of confirmatory factor analyses for social capital dimensions and religiosity

\begin{tabular}{|c|c|c|c|c|}
\hline Latent variable & Indicators & $\begin{array}{c}\text { Factor } \\
\text { loadings }\end{array}$ & $\begin{array}{c}\text { Variance } \\
\text { explained } \\
(\%)\end{array}$ & $\begin{array}{c}\text { KMO } \\
\text { Measure } \\
\text { of } \\
\text { Sampling } \\
\text { Adequacy }\end{array}$ \\
\hline \multirow[t]{3}{*}{ General trust } & Most people can be trusted & 0.85 & \multirow[t]{3}{*}{71.34} & \multirow[t]{3}{*}{0.71} \\
\hline & Most people try to be fair & 0.86 & & \\
\hline & Most of the time people helpful & 0.82 & & \\
\hline \multirow[t]{3}{*}{ Institutional trust } & Trust in country's parliament & 0.84 & \multirow[t]{3}{*}{75.32} & \multirow[t]{3}{*}{0.70} \\
\hline & Trust in the legal system & 0.91 & & \\
\hline & Trust in the police & 0.85 & & \\
\hline \multirow[t]{2}{*}{ Informal networks } & How often socially meet with friends, relatives or colleagues & 0.76 & \multirow[t]{2}{*}{60.13} & \multirow[t]{2}{*}{0.50} \\
\hline & Anyone to discuss intimate and personal matters with & 0.76 & & \\
\hline \multirow[t]{3}{*}{ Civic participation } & Signed petition $\mathrm{s}$ & 0.78 & \multirow[t]{3}{*}{51.04} & \multirow[t]{3}{*}{0.59} \\
\hline & Taken part in lawful public demonstration & 0.65 & & \\
\hline & Boycotted certain products & 0.71 & & \\
\hline \multirow[t]{4}{*}{ Religiosity } & Belonging to particular religion or denomination & 0.78 & \multirow[t]{4}{*}{70.54} & \multirow[t]{4}{*}{0.82} \\
\hline & How religious are you & 0.87 & & \\
\hline & How often attend religious services apart from special occasions & 0.84 & & \\
\hline & How often pray apart from at religious services & 0.87 & & \\
\hline
\end{tabular}


Table A3.

Correlations between the individual-level social capital and personal values

\begin{tabular}{|c|c|c|c|c|c|c|c|c|c|c|c|c|}
\hline & & 1. & 2. & 3. & 4. & 5. & 6. & 7. & 8. & 9. & 10. & 9. \\
\hline 1. & General trust & & & & & & & & & & & \\
\hline 2. & Institutional trust & $\begin{array}{c}0.44^{* *} \\
*\end{array}$ & & & & & & & & & & \\
\hline 3. & $\begin{array}{l}\text { Informal } \\
\text { networks }\end{array}$ & $\begin{array}{c}0.16^{* *} \\
* \\
\end{array}$ & $\begin{array}{c}0.12^{* *} \\
* \\
\end{array}$ & & & & & & & & & \\
\hline 4. & $\begin{array}{l}\text { Civic } \\
\text { participation }\end{array}$ & $\begin{array}{c}0.16^{* *} \\
*\end{array}$ & $\begin{array}{c}0.12 * * \\
*\end{array}$ & $\begin{array}{c}- \\
0.14^{* *} \\
*\end{array}$ & & & & & & & & \\
\hline 5. & $\begin{array}{l}\text { Strong } \\
\text { government }\end{array}$ & $\begin{array}{c}- \\
0.12^{* *} \\
*\end{array}$ & $\begin{array}{c}- \\
0.09 * * \\
*\end{array}$ & $\begin{array}{c}- \\
0.05^{* *} \\
*\end{array}$ & $\begin{array}{c}- \\
0.11 * * \\
*\end{array}$ & & & & & & & \\
\hline 6. & Being modest & $\begin{array}{c}- \\
0.06^{* *} \\
*\end{array}$ & $\begin{array}{c}- \\
0.03^{* *} \\
*\end{array}$ & $\begin{array}{c}- \\
0.06^{* *} \\
*\end{array}$ & $\begin{array}{c}- \\
0.07 * * \\
*\end{array}$ & $\begin{array}{l}0.25^{* *} \\
*\end{array}$ & & & & & & \\
\hline 7. & $\begin{array}{l}\text { Secure } \\
\text { surroundings }\end{array}$ & $\begin{array}{c}- \\
0.13^{* *} \\
*\end{array}$ & $\begin{array}{c}- \\
0.08^{* *} \\
*\end{array}$ & $\begin{array}{c}- \\
0.06^{* *} \\
*\end{array}$ & $\begin{array}{c}- \\
0.14^{* *} \\
*\end{array}$ & $\begin{array}{c}0.48^{* *} \\
*\end{array}$ & $\begin{array}{l}0.29 * * \\
*\end{array}$ & & & & & \\
\hline 8. & Taking risks & $\begin{array}{l}0.02^{* *} \\
\quad *\end{array}$ & $\begin{array}{c}- \\
0.02 * * \\
*\end{array}$ & $\begin{array}{l}0.13^{* *} \\
*\end{array}$ & $\begin{array}{l}0.06^{* *} \\
*\end{array}$ & $\begin{array}{c}- \\
0.02^{* *} \\
*\end{array}$ & $\begin{array}{c}- \\
0.11^{* *} \\
*\end{array}$ & $\begin{array}{c}- \\
0.09^{* *} \\
*\end{array}$ & & & & \\
\hline 9. & Achievement & $\begin{array}{c}- \\
0.05^{* *} \\
*\end{array}$ & $\begin{array}{c}- \\
0.06 * * \\
*\end{array}$ & $\begin{array}{l}0.05^{* *} \\
*\end{array}$ & $\stackrel{-}{-}$ & $\begin{array}{c}0.24^{* *} \\
*\end{array}$ & $\begin{array}{c}- \\
0.02^{* *} \\
*\end{array}$ & $\begin{array}{c}0.20^{* *} \\
*\end{array}$ & $\begin{array}{c}0.39 * \\
* *\end{array}$ & & & \\
\hline 10 & $\begin{array}{l}\text { Understanding } \\
\text { people }\end{array}$ & $\begin{array}{l}0.07 * * \\
*\end{array}$ & $\begin{array}{c}0.07 * * \\
*\end{array}$ & $\begin{array}{l}0.07 * * \\
*\end{array}$ & $\begin{array}{l}0.09 * * \\
*\end{array}$ & $\begin{array}{l}0.22^{* *} \\
*\end{array}$ & $\begin{array}{c}0.30^{* *} \\
*\end{array}$ & $\begin{array}{l}0.20^{* *} \\
*\end{array}$ & $\begin{array}{c}0.08^{*} \\
* *\end{array}$ & $\begin{array}{c}0.14^{*} \\
* *\end{array}$ & & \\
\hline 11 & Independence & $\begin{array}{l}0.02^{* *} \\
*\end{array}$ & 0.00 & $\begin{array}{c}0.07 * * \\
*\end{array}$ & $\begin{array}{c}0.08^{* *} \\
*\end{array}$ & $\begin{array}{c}0.18^{* *} \\
*\end{array}$ & $\begin{array}{l}0.05^{* *} \\
*\end{array}$ & $\begin{array}{c}0.15^{* *} \\
*\end{array}$ & $\begin{array}{c}0.25^{*} \\
* *\end{array}$ & $\begin{array}{c}0.30^{*} \\
* *\end{array}$ & $\begin{array}{c}0.24^{*} \\
* *\end{array}$ & \\
\hline 12 & Loyalty & $\begin{array}{c}0.06^{* *} \\
*\end{array}$ & $\begin{array}{c}0.04 * * \\
*\end{array}$ & $\begin{array}{c}0.12^{* *} \\
*\end{array}$ & $\begin{array}{c}0.07 * * \\
*\end{array}$ & $\begin{array}{c}0.28^{* *} \\
*\end{array}$ & $\begin{array}{c}0.22^{* *} \\
*\end{array}$ & $\begin{array}{c}0.26^{* *} \\
*\end{array}$ & $\begin{array}{c}0.06^{*} \\
* *\end{array}$ & $\begin{array}{c}0.19 * \\
* *\end{array}$ & $\begin{array}{c}0.37 * \\
* *\end{array}$ & $\begin{array}{c}0.28^{*} \\
*\end{array}$ \\
\hline
\end{tabular}

*** significant at the 0.01 level, ** significant at the 0.05 level, * significant at the 0.10 level 
Table A4

Correlations between the individual-level and regional level indicators

\begin{tabular}{|c|c|c|c|c|c|c|c|}
\hline & $\begin{array}{c}\text { Power } \\
\text { distance }\end{array}$ & $\begin{array}{l}\text { Uncertainty } \\
\text { avoidance }\end{array}$ & $\begin{array}{l}\text { Masculi } \\
\text { nity }\end{array}$ & $\begin{array}{l}\text { Indivi- } \\
\text { dualism }\end{array}$ & $\begin{array}{l}\text { Communist back- } \\
\text { ground }\end{array}$ & $\begin{array}{l}\text { General } \\
\text { religiosity }\end{array}$ & $\begin{array}{c}\text { Share of hier. } \\
\text { religion }\end{array}$ \\
\hline General trust & $-0.39 * * *$ & $-0.36 * * *$ & $\begin{array}{c}- \\
0.35^{* * *}\end{array}$ & $0.13^{* * *}$ & $-0.25^{* * *}$ & $-0.24 * * *$ & $-0.36 * * *$ \\
\hline $\begin{array}{l}\text { Institutional } \\
\text { trust }\end{array}$ & $-0.47 * * *$ & $-0.37 * * *$ & $\begin{array}{c}- \\
0.33^{* * *}\end{array}$ & $0.20 * * *$ & $-0.37 * * *$ & $-0.14 * * *$ & $-0.30 * * *$ \\
\hline $\begin{array}{l}\text { Informal } \\
\text { networks }\end{array}$ & $-0.18^{* * *}$ & $-0.16 * * *$ & $\begin{array}{c}- \\
0.18^{* * *}\end{array}$ & $0.03 * * *$ & $-0.17 * * *$ & $-0.09 * * *$ & $-0.10 * * *$ \\
\hline $\begin{array}{l}\text { Civic } \\
\text { participation }\end{array}$ & $-0.24 * * *$ & $-0.26^{* * *}$ & $\begin{array}{c}- \\
0.24^{* * *}\end{array}$ & $0.09 * * *$ & $-0.22 * * *$ & $-0.15^{* * *}$ & $-0.20 * * *$ \\
\hline $\begin{array}{l}\text { Strong } \\
\text { government }\end{array}$ & $0.19 * * *$ & $0.26 * * *$ & $0.18^{* * *}$ & $-0.02 * * *$ & $0.13^{* * *}$ & $0.10 * * *$ & $0.15^{* * *}$ \\
\hline Being modest & $0.09 * * *$ & $0.12^{* * *}$ & $0.06^{* * *}$ & $0.02 * * *$ & 0.00 & $0.05^{* * *}$ & $0.10^{* * *}$ \\
\hline $\begin{array}{l}\text { Secure } \\
\text { surroundings }\end{array}$ & $0.17 * * *$ & $0.26^{* * *}$ & $0.18^{* * *}$ & $0.02 * * *$ & 0.11 *** & $0.13 * * *$ & $0.16^{* * *}$ \\
\hline Taking risks & $-0.03 * * *$ & $0.01^{* *}$ & $0.05^{* * *}$ & $0.05^{* * *}$ & $-0.03 * * *$ & $0.02^{* * *}$ & 0.00 \\
\hline Achievement & $0.13 * * *$ & $0.16^{* * *}$ & $0.22 * * *$ & $0.03 * * *$ & $0.14 * * *$ & $0.09 * * *$ & $0.09 * * *$ \\
\hline $\begin{array}{l}\text { Understanding } \\
\text { people }\end{array}$ & $-0.06 * * *$ & 0.00 & $\begin{array}{c}- \\
0.02 * * *\end{array}$ & $0.12^{* * *}$ & $-0.12 * * *$ & $0.02 * * *$ & 0.01 \\
\hline Independence & $-0.07 * * *$ & $-0.01 * *$ & -0.01 & $0.14 * * *$ & $-0.09 * * *$ & 0.00 & $-0.04 * * *$ \\
\hline Loyalty & $-0.06 * * *$ & $-0.02^{* * *}$ & $\begin{array}{c}- \\
0.04 * * *\end{array}$ & $0.10^{* * *}$ & $-0.11 * * *$ & $-0.02 * * *$ & $-0.03 * * *$ \\
\hline
\end{tabular}

*** significant at the 0.01 level, ** significant at the 0.05 level, * significant at the 0.10 level

Table A5

Correlations between the regional level indicators (regional level correlations)

\begin{tabular}{|c|l|c|c|c|c|c|c|}
\hline & & 1. & 2. & 3. & 4. & 5. & 6. \\
\hline 1. & Power distance & & & & & & \\
\hline 2. & Uncertainty avoidance & $0.72^{* * *}$ & & & & & \\
\hline 3. & Masculinity & $0.55^{* * *}$ & $0.70^{* * *}$ & & & & \\
\hline 4. & Individualism & $-0.30^{* * *}$ & 0.04 & 0.09 & & & \\
\hline 5. & Communist background & $0.70^{* * *}$ & $0.47^{* * *}$ & $0.54^{* * *}$ & $-0.45^{* * *}$ & & \\
\hline 6. & General religiosity & $0.38^{* * *}$ & $0.54^{* * *}$ & $0.74^{* * *}$ & -0.13 & $0.44^{* * *}$ & \\
\hline 7. & Share of hierarchic religion & $0.51^{* * *}$ & $0.60^{* * *}$ & $0.66^{* * *}$ & $-0.20^{*}$ & $0.46^{* * *}$ & $0.85^{* * *}$ \\
\hline
\end{tabular}

*** significant at the 0.01 level, ** significant at the 0.05 level, * significant at the 0.10 level 